Received 11.02.2017 Reviewed 03.05.2017 Accepted 24.05.2017

A - study design

B - data collection

C - statistical analysis

D - data interpretation

$\mathbf{E}$ - manuscript preparation

F - literature search

\section{Mapping of soil erodibility and assessment of soil losses using the RUSLE model in the Sebaa Chioukh Mountains (northwest of Algeria)}

\author{
Maamar MEGHRAOUI ${ }^{1)}$ ABDEF $ه$, Mohamed HABI ${ }^{2)}$ ADEF, \\ Boutkhil MORSLI ${ }^{3)}$ ADEF, Mohamed REGAGBA ${ }^{\text {3) ABD, }}$ \\ Abdelhakim SELADJI ${ }^{3)}$ ABD
}

\footnotetext{
${ }^{1)}$ University of Tlemcen, Department of Forest Resources, BP88, Mansourah Tlemcen, Algeria, 13000 Tlemcen, Algeria; e-mail: meghraoui_forestier@yahoo.fr

2) University of Tlemcen, Department of Hydraulic, BP 230, Tlemcen 13000, Algeria; e-mail: moha.habi@gmx.de

${ }^{3)}$ National Institute for Forest Research, BP 88, Tlemcen 13000, Algeria; e-mail: morsli_boutkhil@yahoo.fr, regmoha@hotmail.com, abseladji@yahoo.fr
}
For citation: Meghraoui M., Habi M., Morsli B., Regagba M., Seladji A. 2017. Mapping of soil erodibility and assessment of soil losses using the RUSLE model in the Sebaa Chioukh Mountains (northwest of Algeria). Journal of Water and Land Development. No. 34 p. 205-213. DOI: 10.1515/jwld-2017-0055.

\begin{abstract}
In Algeria, erosion and solid transport constitute a major constraint to the development of agriculture and to the management of hydrotechnical works (more than $20 \%$ are silted). Due to the irregular rains that characterize the Mediterranean semi-arid zones, the topography of the mountainous areas, the fragility of the soils, the absence of vegetation cover and the inappropriate cropping systems, the Sabaa Chioukh Mountains shows a dissected topography, frequent and violent floods. It is therefore absolutely important and crucial to assess, spatially and quantitatively, the effects of soil erosion in order to face the phenomenon and to propose the best strategies for conservation and land management. This study aims to map the soils erodibility, using remote sensing, and Geographic Information Systems (GIS) taking into account the soil types. In order to achieve the objective, we calculated the factors of the RUSLE equation. The results obtained showed that 26,760 ha i.e. $56.58 \%$ of our study area are exposed to an annual soil loss of 150 to $200 \mathrm{t} \cdot \mathrm{ha}^{-1}$. These areas are located in fersiallitic soils and vertisols and especially in non-cultivable areas which have high slope values.
\end{abstract}

Key words: GIS, remote sensing, RUSLE, Sebaa Chioukh Mountains

\section{INTRODUCTION}

Erosion in Algeria is a serious environmental, agricultural and social problem that affects and threatens huge areas of our country. Nearly 50 million hectares are threatened by desertification and water erosion, of which 14 million hectares in mountain areas are affected by water erosion MostePHAOUI et al. [2013]. It is therefore imperative to assess spatially and quanti- tatively the effects of soil erosion and to propose the best control strategies.

Our objective is the detection of eroded areas in the Sebaa Chioukh Mountains as well as the assessment of the factors controlling erosion and their characteristics and the specialisation with the RUSLE empirical equation (Revised Universal Soil Loss Equation, established by RENARD et al. [1997]. This study makes it possible to quantify the soil in tons per hec- 
tare which can be unleashed annually. This is achieved through two complementary ways:

- mapping of soil erodibility by processing the LANDAST satellite image followed by soil analysis of the taken samples;

- integration of the erosion assessment model (RUSLE) into a geographic information system, in order to locate the priority areas for possible management intervention.

\section{PRESENTATION OF THE STUDY AREA}

Geographically the Sebaa Chioukh mountains are part of the interior Tellian mountain range, and are located in the northwest of Algeria between the following geographical coordinates: $1^{\circ} 27^{\prime} 1,67^{\prime \prime}$ and $0^{\circ} 58^{\prime} 3^{\prime \prime} \mathrm{W}$ and $35^{\circ} 3^{\prime} 16.8^{\prime \prime}$ and $35^{\circ} 13^{\prime} 44.7^{\prime \prime} \mathrm{N}$. This mountain range extends over an area of $475 \mathrm{~km}^{2}$, from Dioussiane Djebel $(627 \mathrm{~m})$ to the Tessala Mounts from West to East. The summits, located to the west at about $5 \mathrm{~km}$, south of Aïn Kihal, at Aïn Taqbalet, and at the East in the Touil Djebel at Aoubellil, culminate respectively at $684 \mathrm{~m}$ and $824 \mathrm{~m}$. The heights extend parallel to the dominant outcrops of the limiting ridges. This space represents a well-identified geographical entity considering its rugged relief of EastWest orientation, overlapping the Wilayas of Tlemcen and Aïn Témouchent (Fig. 1).

The climate of the study area is Mediterranean: semi-arid with relatively low annual rainfall ranging from 400 to $600 \mathrm{~mm}$. According to lithology map, the Mountains of Sabaa Chioukh reflect a great diversity of surface formations with predominance of friable limestones and clay soils derived from marl formations. The dominant cropping system in the Sebâa Chioukh Mountains is the cereal / fallow association which occupies nearly $42 \%$ of the utilised agricultural land. The latter does not reflects the actual vocation of the zone. Annual crops remain largely dominant to the detriment of perennial crops recognized for their role as a soil fixer.

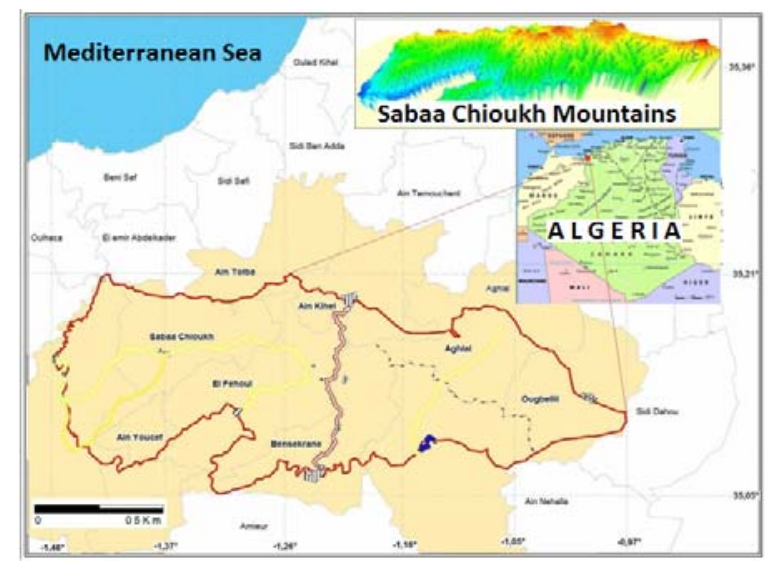

Fig. 1. Location map of the Mounts of Sebaa Chioukh (Algeria); source: own elaboration

\section{MATERIALS AND METHODS}

Our methodological approach was based on two steps.

1. Soil erodibility mapping: soil erodibility is an estimate of the soil's ability to withstand erosion based on the physical characteristics of each soil WALL et al. [1987]. The mapping was done on the basis of a 9.09.2011 multi spectral satellite image, knowing that the satellite images make it possible to obtain pedological information such as colour, organic and calcareous contents, surface stones, roughness, depth and texture of the soil [GIRARD, GIRARD 1999]. The image processing was done with the ENVI software, by a maximum likelihood-type supervised classification using TM trichromy (7.5.1), and then allowed us to make an inventory on the large soil units, by soil-landscape mapping, which defined by [GIRARD 1983] as a set of soil horizons and landscape elements. Even the works done by GIRARD [1975; 1977], NAERT [1977], EscADAFAL [1989], KING [1994] and ESCADAFAL et al. [1995] show that a synthesis information represented by the concept of pedolandscaping or descending mapping is sufficient in a first time, to know the major classes of soils. It will be introduced, in a second step, in a geographical information system (GIS) in order to orient the land use towards a suitable development, and then one can move to the scale of the plot.

The sampling sites for soil analysis and observation were chosen on the basis of the areas which show approximately the different spectral responses of the TM trichromy (7.5.1); see Figure 2.

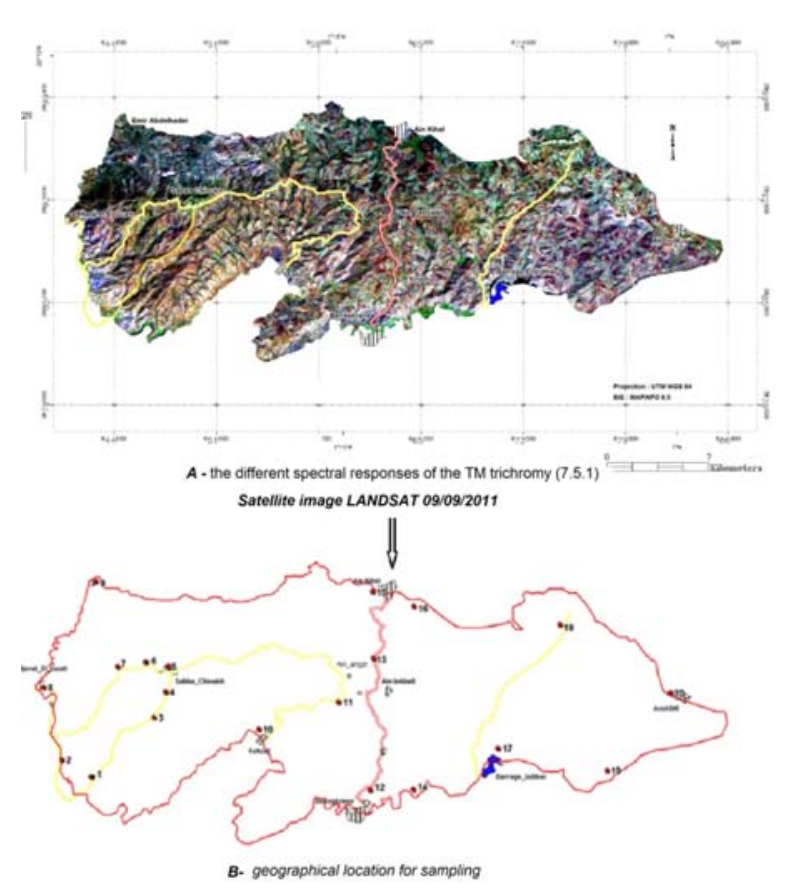

Fig. 2. Sampling of the soil as a function of the spectral response: a) satellite image Landsat 09/09/2011, b) geographical location for sampling; source: own elaboration 
After the creation of soil-landscape map, which includes the large soil-landscape units, the erodibility of each soil unit was defined, for the value of $K$ estimated using the [WISCHMEIER, MANNERING 1969] nomogram which takes into account the properties of the soil, of the content of silt and the very fine sand $(0.002-0.1 \mathrm{~mm})$, the sand content $(0.1-2.0 \mathrm{~mm})$, the organic matter content, the surficial horizon structure, the permeability and the profile depth. These five parameters are introduced successively into an abacus, which makes it possible to easily obtain the value of the $K$ factor for a given soil [BOLLINE, ROSSEAU 1978].
2. The second step of our methodological approach consists in the integration and representation of cartographic and descriptive information on the different factors and parameters of erosion in a geographic information system platform.

However, the RUSLE model is selected from the most applicable models due to its very simple structure and the thrifty entry of data in relation to the available data and the scale of the investigation KHALI ISSA et al. [2016]. The equation has been integrated under a geographic information system to allow modelling and an exhaustive mapping of the erosive phenomenon. Our approach is illustrated in Figure 3.

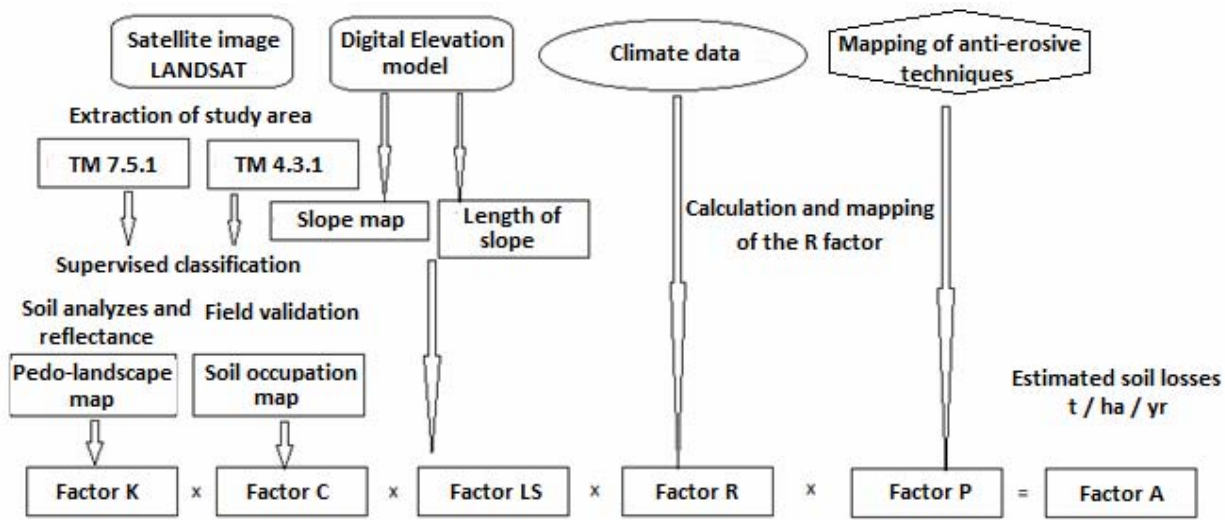

Fig. 3. Schematic of the methodological approach; source: own elaboration

\section{RESULTS AND DISCUSSION}

1. Synthetic pedo-landscape Map: from analyses carried out on soil samples, parameters such as particle size, $\mathrm{pH}$, total limestone, carbon, and organic matter and colour were determined in Table 1.

The creation of the soil-landscape map allowed us to identify 06 soil units (Tab. 2) distributed spatially according to the relief, the lithological substratum and the vegetation (Fig. 4).

1.1. Fersiallitic soils: they are with calcium reserve and they occupy an area of 20210 ha, or $42.57 \%$ of the study area, or without calcium reserve over an area of 1395 ha, or $2.94 \%$ of the study area. These two units show high erodibility, about 0.38 to 0.46 .

1.2. Vertisols: they are, in fact, very clayey soils, consisting of swelling clays. This unit occupies 15650 ha, or $32.96 \%$ with a high erodibility at about 0.35 to 0.38 .

1.3. Soils not well evolved from erosion: these young soils settle on soft materials (clays), this unit occupies a less important area about 803.7 ha or $1.69 \%$, and an erodibility in the order of 0.23 to 0.35 .

Table 1. Results of soil analyses

\begin{tabular}{|c|c|c|c|c|c|c|}
\hline \multirow{2}{*}{ No. } & \multirow{2}{*}{$\mathrm{pH}$} & \multirow{2}{*}{$\begin{array}{l}\text { Limestone } \\
\mathrm{CaCO}_{3}, \%\end{array}$} & \multicolumn{2}{|c|}{ Organic material } & \multirow{2}{*}{ Granulometry texture } & \multirow{2}{*}{ Colour } \\
\hline & & & $\mathrm{C} \%$ & $\mathrm{M}, \mathrm{O} \%$ & & \\
\hline 1 & 7.70 & 19.50 & 0.46 & 0.80 & clay loam & brownish black $3 / 1$ \\
\hline 2 & 7.83 & 30.06 & 0.61 & 1.06 & loam & grayish yellow brown $6 / 2$ \\
\hline 3 & 7.95 & 17.81 & 1.04 & 1.79 & clay loam & grayish yellow $6 / 2$ \\
\hline 4 & 7.84 & - & 0.85 & 1.46 & clay loam & brownish black $3 / 1$ \\
\hline 5 & 7.90 & 13.31 & 1.08 & 1.86 & loam & yellowish brown $5 / 3$ \\
\hline 6 & 7.90 & 6.70 & 0.23 & 0.40 & loam & dull reddish brown $5 / 3$ \\
\hline 7 & 7.96 & - & 1.31 & 2.26 & sandy clay loam & brown $4 / 6$ \\
\hline 8 & 7.93 & 0.73 & 0.46 & 0.80 & sandy clay & reddish brown $4 / 6$ \\
\hline 9 & 7.79 & - & 1.62 & 2.79 & loamy sand & reddish brown $4 / 6$ \\
\hline 10 & 8.23 & 31.72 & 0.23 & 0.40 & clay & grayish yellow brown $6 / 2$ \\
\hline 11 & 8.00 & 8.93 & 1.23 & 2.13 & loam & dull reddish brown $4 / 4$ \\
\hline 12 & 7.99 & 40.83 & 1.08 & 1.86 & loam & dull yellow orange $6 / 4$ \\
\hline 13 & 7.93 & 33.92 & 2.39 & 4.12 & loamy sand & brownish black $3 / 2$ \\
\hline 14 & 7.79 & 18.41 & 2.47 & 4.26 & loam & dark reddish brown $3 / 2$ \\
\hline 15 & 7.81 & 22.05 & 0.96 & 1.66 & clay & yellowish brown $5 / 3$ \\
\hline
\end{tabular}

Source: own study. 
Table 2. The soil units of the study area

\begin{tabular}{|l|r|r|c|}
\hline \multicolumn{1}{|c|}{ Soil unit } & \multicolumn{1}{c|}{$\begin{array}{c}\text { Area } \\
\text { ha }\end{array}$} & $\%$ & $\begin{array}{c}\text { Erodi- } \\
\text { bility }\end{array}$ \\
\hline Brown calcareous calcimagnesic soils & 7373 & 15.53 & $0-0.23$ \\
\hline Vertisols & 15650 & 32.96 & $0.35-0.38$ \\
\hline Fersiallitic soil with calcium reserve & 20210 & 42.57 & $0.38-0.46$ \\
\hline Fersiallitic soil without calcium reserve & 1395 & 2.94 & $0.38-0.46$ \\
\hline Soils not well evolved from erosion & 803.7 & 1.69 & $0.23-0.35$ \\
\hline Iso-humic soils & 1864 & 3.93 & $0.38-0.46$ \\
\hline
\end{tabular}

Source: own study.
1.4. Brown calcareous calcimagnesic soils: they are soils which release sufficient quantities of active limestone. They are deeper and, above all, much richer. These soils occupy an area of 7373 ha, or $15.53 \%$. This soil unit is resistant to erosion with erodibility of 0 to 0.23 .

1.5. Iso-humic soils: these soils are less important in our study area with 1864 ha, or $3.93 \%$ with erodibility of 0.38 to 0.46 .

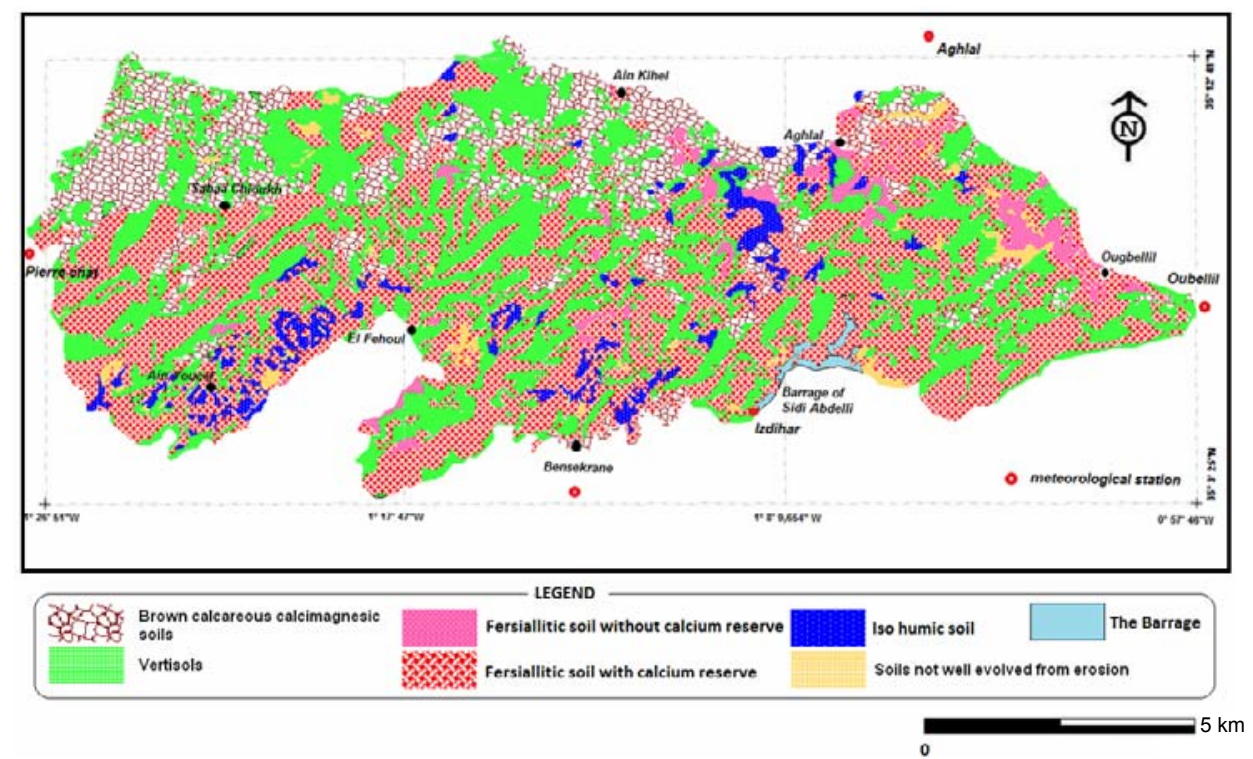

Fig. 4. Pedo-landscap map of Sabaa Chioukh Mountains; source: own elaboration

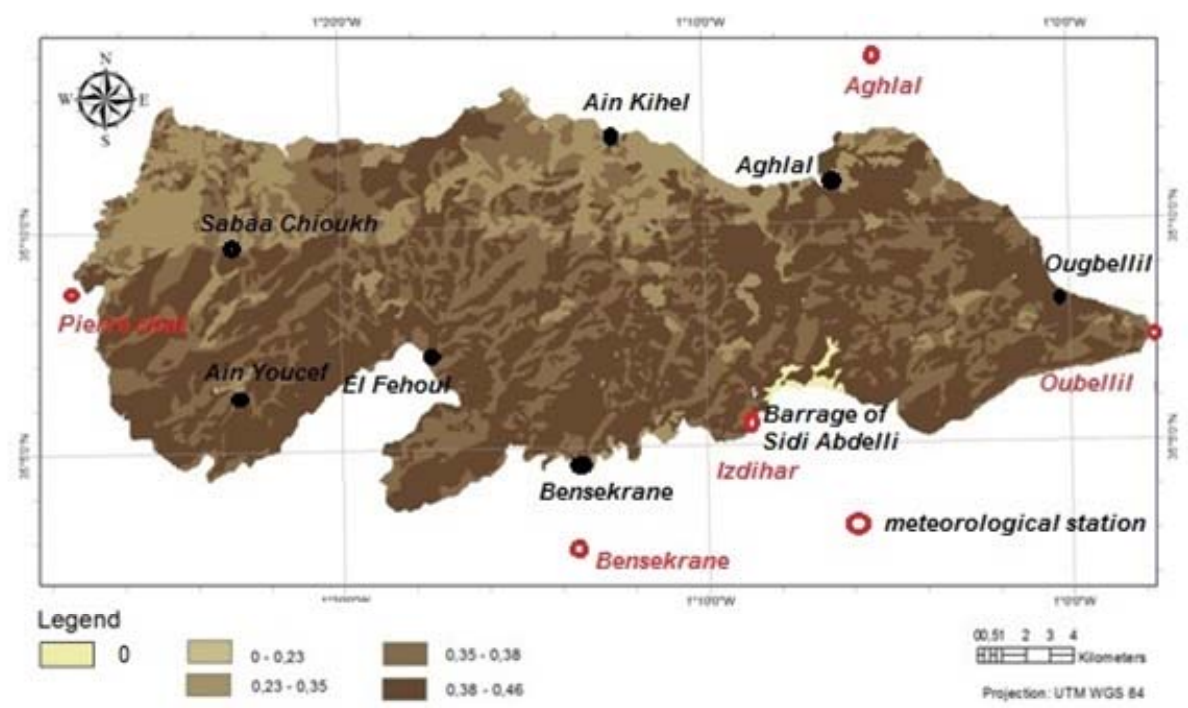

Fig. 5. Erodibility of soil (factor $K$ ); source: own elaboration

\section{RUSLE Factor Mapping}

2.1. Soil erodibility (factor $K$ ): Figure 5 shows the spatial distribution of the different $K$ factor classes in the mountain massif of Sebaa Chioukh. The values of the erodibility index are between 0 and 0.46 and are distributed in the study area according to the different soil units. The study area generally has an average erodibility $(0.38-0.46)$ covering almost the total area
$(78.48 \%)$, on the fersiallitic soils and vertisols, followed by a low erodibility $(0-0.23)$ or $15.53 \%$ located in the northern side of the massif on the calcareous brown limestone soil unit.

2.2. Vegetation cover (factor $\boldsymbol{C}$ ): factor $C$ is defined as the ratio between bare soil losses under specific conditions and soil losses corresponding to soils under operating system [WISCHMEIER, SMITH 1978] in (EL 
GAROUANI et al. [2008]). This factor was estimated from the land use map which represents the effects of vegetation, management, and erosion control and realized by processing the LANDSAT image by the ENVI software, using the supervised classification of the maximum likelihood of Trichromy TM (4.3.1). It allowed us to establish the units that occupy the soil of the mountainous massif of Sebaa Chioukh.

The land use map (Fig. 6) shows that our study area is dominated by bare soils and badlands "the ultimate stage of erosion", see Table 3 , with an area of 23225.5 ha or $49.1 \%$, and a higher $\mathrm{C}$ factor (around $0.75)$, since the vegetation cover protects the soils and ensures the damping of the raindrops. Soil losses decrease with the increase of the vegetation cover SOUTTER et al. [2007]. But our zone has only a small area of this protective class "clear forests", which appears with a red colour (see Fig. 7) with about 3510.5 ha, or $7.42 \%$.

Table 3. Land use of the study area

\begin{tabular}{|l|c|c|c|}
\hline \multicolumn{1}{|c|}{ Land use } & Area, ha & $\%$ & Factor $C$ \\
\hline Clear forests & 3510.5 & 7.42 & 0.08 \\
\hline Crop fields & 3575.2 & 7.55 & 0.25 \\
\hline Rangelands & 16712.5 & 35.33 & 0.26 \\
\hline Bare soils and badlands & 23225.5 & 49.10 & 0.75 \\
\hline Water surface & 271.4 & 0.57 & - \\
\hline
\end{tabular}

Source: own elaboration.

2.3. Factor $\boldsymbol{L S}$ : this factor (Fig. 8) shows the importance of slope angle and length in the processes of sheet and gully erosion. It generally reflects the terrain topography. The topographic data were obtained from a digital elevation model "DEM". This factor was calculated by the WISCHMEIER and SMITH [1978] in (SADIKI et al. [2004]):

$$
L S=(L / 23.13) m \cdot(0.065+0.045 S+0.065 S 2)
$$

where: $L=$ the slope length, $\mathrm{m} ; S=$ the slope angle, $\% ; m=$ a parameter such as $m=0.5$ if the slope $>5 \%$; 0.4 if the slope is 3.5 to $4.5 \%$; 0.3 if the slope is 1 to $3 \%$ and 0.2 if the slope is $<10 \%$.

2.4. Factor $\boldsymbol{R}$ : the erosivity or erosive aggressiveness of rainfall is the parameter used to estimate the ability of rain to produce slope erosion (including the formation of small rills) by integrating over a period of time all events likely to contribute [BORGES 2012].

Given the absence of some meteorological information $\left(I_{30}\right.$, the maximum intensity of rain in $\left.30 \mathrm{~min}\right)$, only the annual rainfall of the five meteorological stations was computed, for the Sebaa Chioukh mountain massif, applying the Fournier rainfall aggressiveness: $R=0.03 P^{1.288}(P=$ annual rainfall $)$ using the geostatistical module with the ArcGis software. These results are summarized in Table 4 and Figure 9.

2.5. Factor $\boldsymbol{P}$ : the practical support factor $(P)$ in RUSLE expresses the influence of conservation methods on erosion. The $P$ factor reflects the used cultivation techniques (land management modes such
Table 4. Meteorological station of study area

\begin{tabular}{|l|c|c|}
\hline Station & Annual rainfall, $\mathrm{mm}$ & Factor $R$ \\
\hline Aghlal & 475 & 84.08 \\
\hline Izdihar & 431 & 74.18 \\
\hline Bensekrane & 424 & 72.63 \\
\hline Pierre chat & 376 & 62.22 \\
\hline Oubellil & 491 & 87.74 \\
\hline
\end{tabular}

Source: own study.

as; plowing mode and crops direction) and soil conservation measures (slopes re-vegetation) BOUGUERRA et al. [2017]. It is equal to the unit for a soil cultivated in the direction of the slope, according to SCHWAB et al. [1966]. They analysed numerous plots or different conservation systems, conservation factors were determined and are presented in Table 5 and Figure 10.

Table 5. Recommended and adapted conservation factors by SCHWAB et al. [1966]

\begin{tabular}{|c|c|c|c|}
\hline Slope, \% & Contouring & In band & $\begin{array}{c}\text { Terrace with con- } \\
\text { tour cultures }\end{array}$ \\
\hline $\begin{array}{l}\text { Parallel to field } \\
\text { boundaries }\end{array}$ & 0.8 & - & - \\
\hline $1.0-2.0$ & 0.6 & 0.30 & - \\
\hline $2.1-4.0$ & 0.5 & 0.25 & 0.10 \\
\hline $4.1-7.0$ & 0.5 & 0.25 & 0.10 \\
\hline $7.1-12.0$ & 0.6 & 0.30 & 0.12 \\
\hline $12.1-18.0$ & 0.8 & 0.40 & 0.16 \\
\hline Sup 18.0 & 0.9 & 0.45 & - \\
\hline
\end{tabular}

Source: own study.

The $P$ factor was estimated from the land use map and the reclassified slopes map according to the method of SCHWAB et al. [1966] adapted from the works of [SMITH, WISCHMEIER 1957; 1962].

2.6. Factor $\boldsymbol{A}$ (annual soil losses): the superposition of maps of different factors involved in soil water erosion yielded a map of soil losses at any point in the mountain massif of Sebaa Chioukh (Fig. 11). Thus the losses are about 150 to $200 \mathrm{t} \cdot \mathrm{ha}^{-1} \cdot \mathrm{yr}^{-1}$ on an area of 26760 ha, or $56.58 \%$ of the territory, due to the erodibility of the fersiallitic soils and vertisols and especially in bare soils and badlands, which have high slope values (Tab. 6). The second class of 100 to 150 $\mathrm{t} \cdot \mathrm{ha}^{-1} \cdot \mathrm{yr}^{-1}$ is also important with an area of $13690 \mathrm{ha}$, or $28.94 \%$ of the territory, is observed in the eastern part; this is mainly explained by the steep slope with the fersiallitic soils and vertisols dominance despite the presence of a sparse vegetal cover. In the northern side of the massif, soil losses are lower, about 50 to 100 $\mathrm{t} \cdot \mathrm{ha}^{-1} \cdot \mathrm{yr}^{-1}$, i.e. $6.52 \%$ of the territory. Dominance of calcareous brown calcimagnesic soils, with low erodibility (0.23), helps to reduce soil losses, and especially with the presence of a vegetal cover. The class of $0-50 \mathrm{t} \cdot \mathrm{ha}^{-1} \cdot \mathrm{yr}^{-1}$ coincides with areas of clear forest on calcareous brown calcimagnesic soil, and especially at peaks where the slope is less, this class covers an area of 3482.7 ha, or $7.36 \%$ of the territory. 


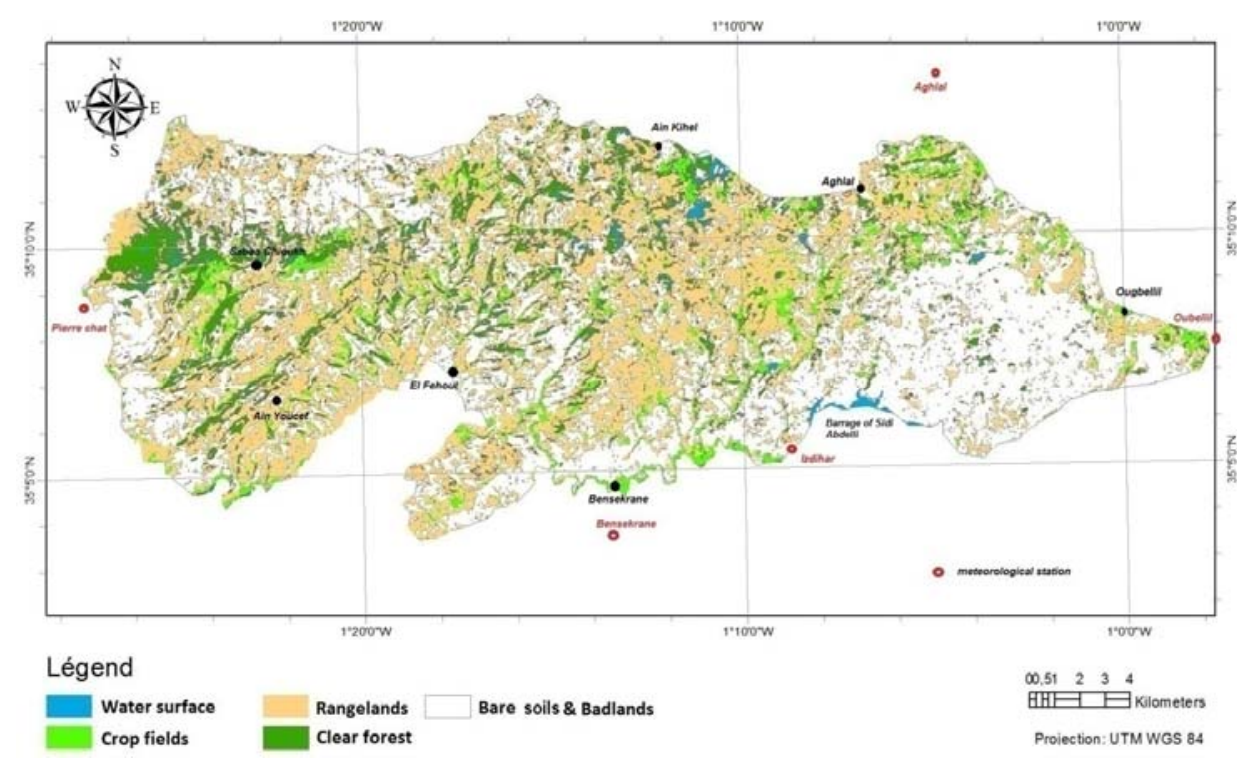

Fig. 6. Land use of the study area; source: own study

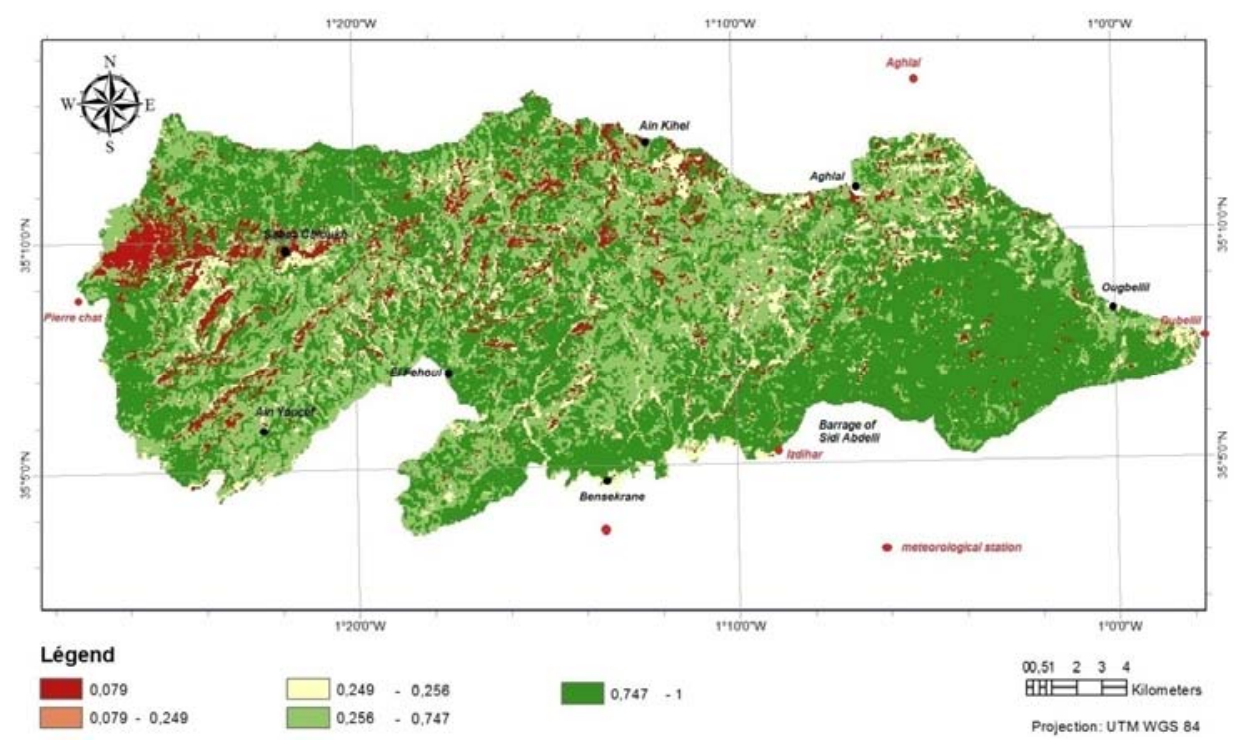

Fig. 7. Factor C (land use); source: own study

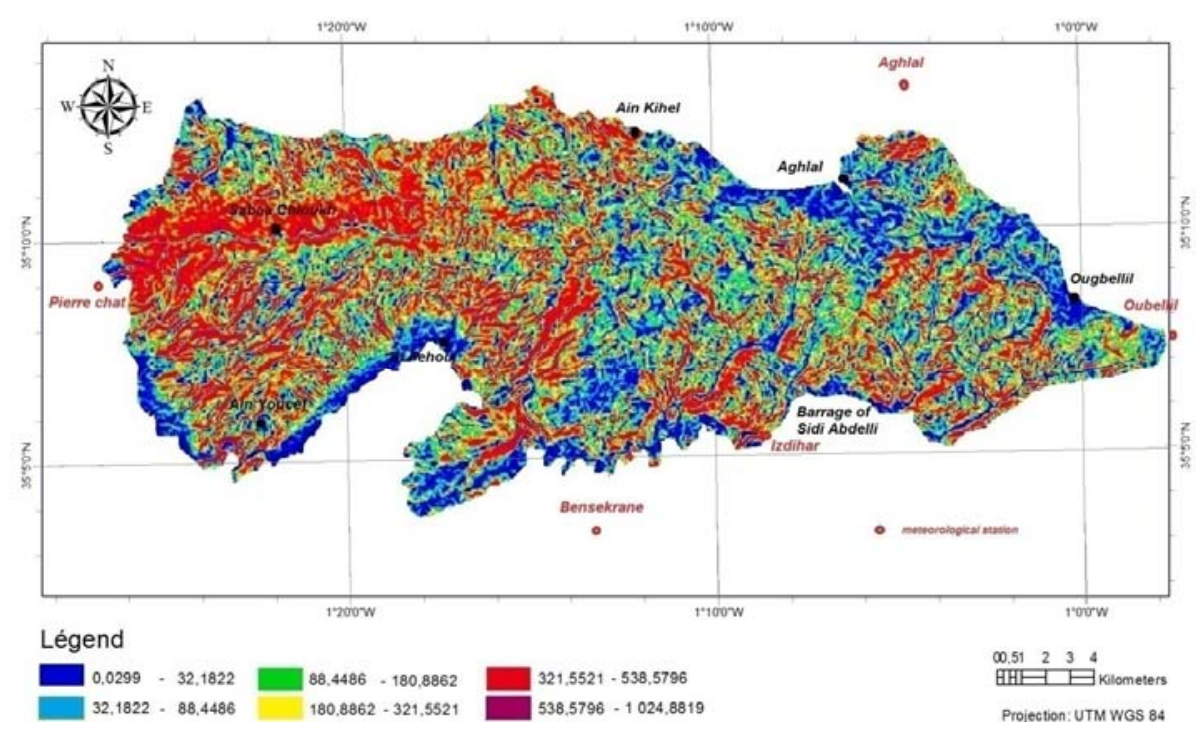

Fig. 8. Factor $L S$ (length of slope); source: own study 


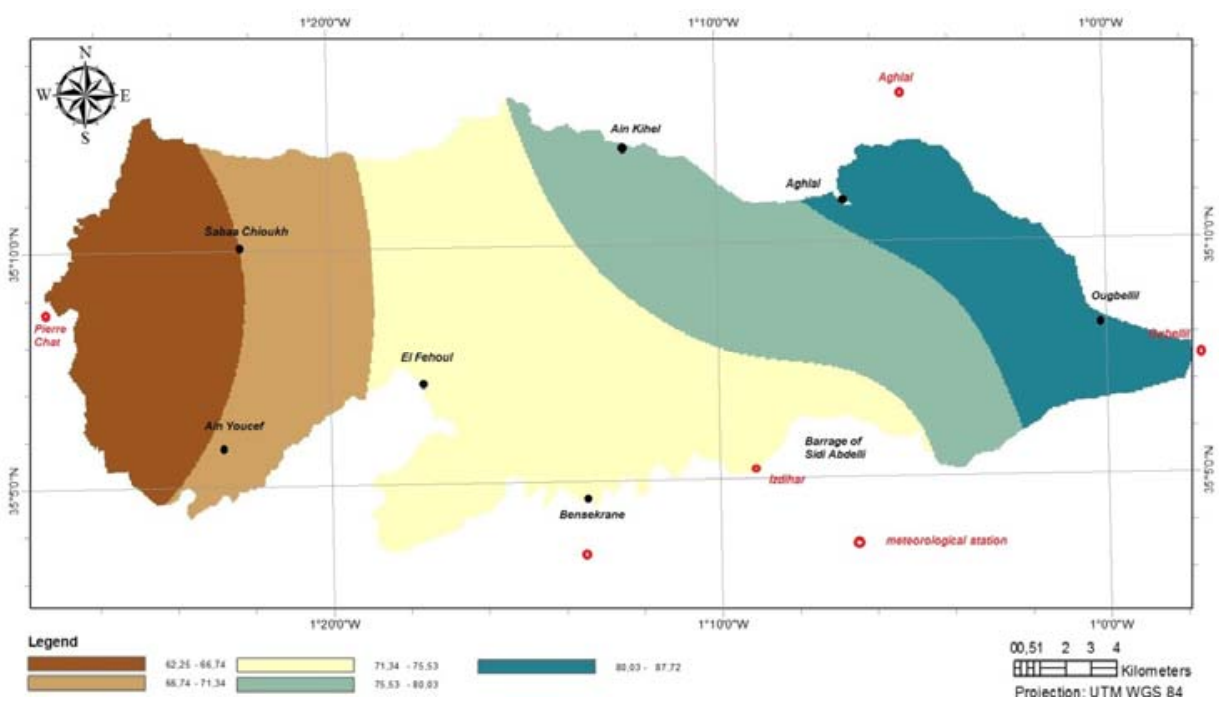

Fig. 9. Factor $R$ (aggressivity of rainfall); source: own study

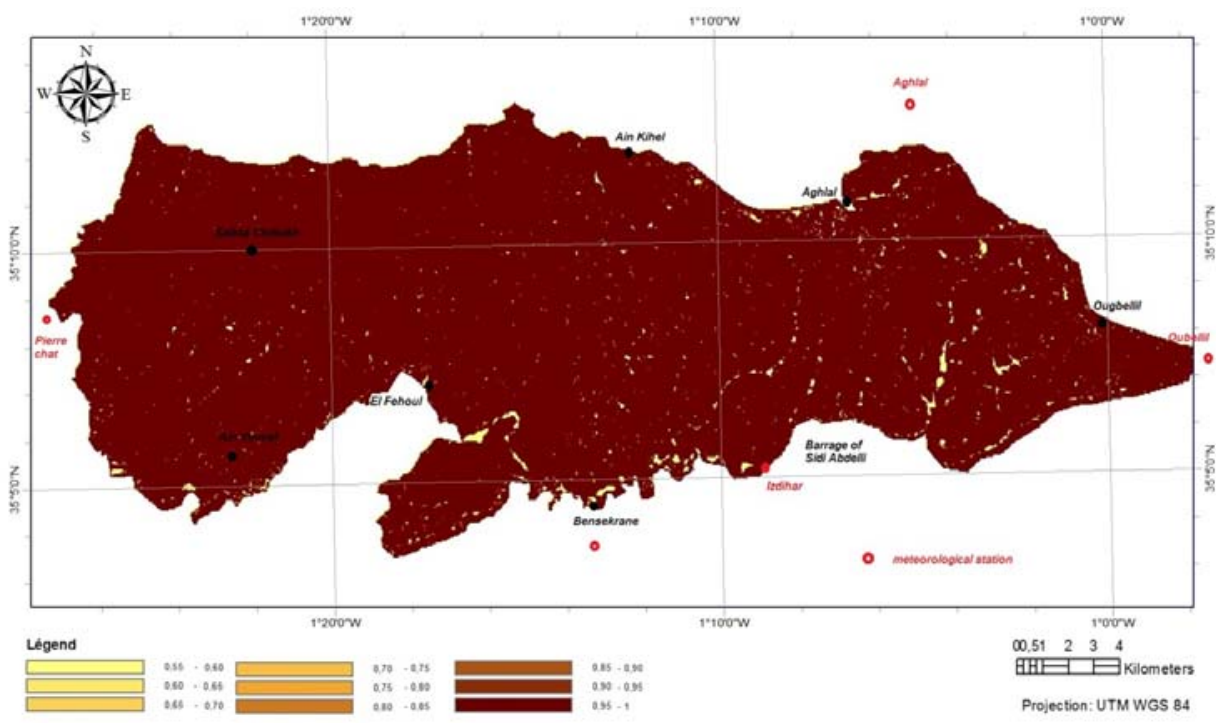

Fig. 10. Factor $P$ (practice factor); source: own study

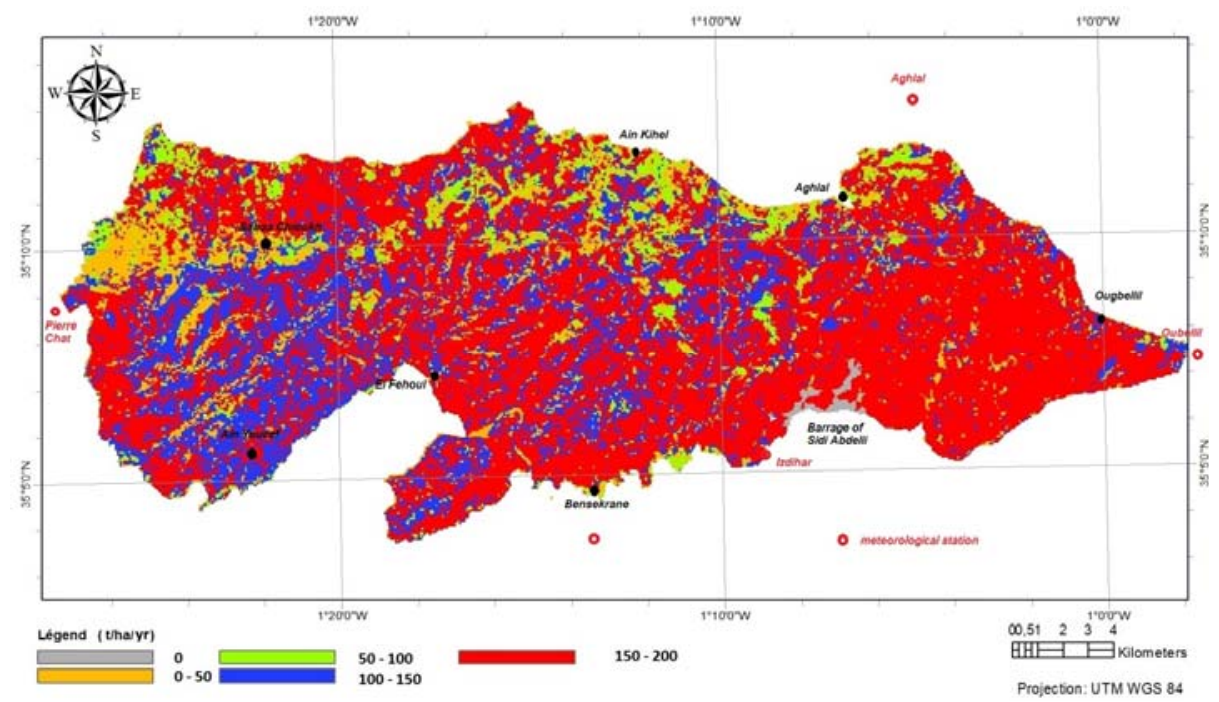

Fig. 11. Factor $A$ (annual average soil loss); source: own study 
Table 6. Annual average soil loss

\begin{tabular}{|c|r|c|}
\hline $\begin{array}{c}\text { Factor } A \\
\mathrm{t} \cdot \mathrm{ha}^{-1} \cdot \mathrm{yr}^{-1}\end{array}$ & Area, ha & $\%$ \\
\hline 0 & 276.0 & 0.58 \\
\hline $0-50$ & 3482.7 & 7.36 \\
\hline $50-100$ & 3086.3 & 6.52 \\
\hline $100-150$ & 13690.1 & 28.94 \\
\hline $150-200$ & 26760.0 & 56.58 \\
\hline
\end{tabular}

Source: own study.

\section{CONCLUSIONS}

During this work, our aim was to analyse the spatial variability of soil erodibility, based on the synthetic pedo-landscape map, which determines the soillandscape relationship, using satellite imagery and analyses of the soil. The average erodibility is 0.38 to 0.46 covering almost the total area $(78.48 \%)$. It is related to the internal nature of the soil, thus playing an important role in erosion, including the texture, structure, organic matter content and permeability. The erosion map has also been developed which provides extensive information on the potential for sediment production at the scale of the mountain massif of Sebaa Chioukh, yielding an annual loss of 150-200 t.ha ${ }^{1}$ on $56.58 \%$ of the territory. This value is well above the tolerable threshold, it is favoured by erosion factors which also combine to accelerate erosion, significant losses (nearly $70 \%$ of the total area of the massif have a very steep slope), moderately erodible soils (78.48\% of the soils show a $K$ factor between 0.38 and 0.46$)$, a degraded vegetation cover $(49.1 \%$ of bare soils and badlands), and an index of climatic aggressiveness ranging from 62.22 to 87.74 .

The GIS has made it possible to manage rationally the different factors of soil degradation, it gives us relatively reliable results that can provide valuable help to forest managers in order to simulate evolution scenarios and, target priority areas that require conservation and erosion control actions.

\section{REFERENCES}

Bollinne A., Rosseau P. 1978. Erodibilité des sols de moyenne et haute Belgique, utilisation d'une méthode de calcul du facteur $K$ de l'équation universelle de perte en terre [The soil erodibility of the medium and high Belgium, using a method of calculating the $K$ factor of the universal soil loss equation]. Bulletin Société Belge d'Etudes Géographiques. Vol. 14. Iss. 4 p. 127-140.

Borges A.L. 2012. Modélisation de l'erosion sur deux bassins versants expérimentaux des Alpes du Sud [Modeling of erosion on two experimental watersheds in the Southern Alps]. Thèse de doctorat. Grenoble I. Université Joseph Fourier pp. 259.

Bouguerra H., Bouanani A., Khanchoul K., Derdous O., TACHI S.E. 2017. Mapping erosion prone areas in the Bouhamdane watershed (Algeria) using the Revised Universal Soil Loss Equation through GIS. Journal of Water and Land Development. No. 32 p. 13-23.

El Garouani A., Chen H., Lewis L., TribaK A., ABAHrour M. 2008. Cartographie de l'utilisation du sol et de l'érosion nette à partir d'images satellitaires et du SIG Idrisi au nord-est du Maroc [Mapping of the use of the soil and the net erosion from satellite images and GIS Idrisi in the northeast of the Morocco]. Télédétection. Vol. 8 p. 193-201.

ESCADAFAL R. 1989. Caractérisation de la surface des sols arides par observation de terrain et par télédétection. Applications: exemple de la région de Tataouine (Tunisie) [Characterization of the surface of arid soils by field observation and remote sensing. Applications: example from the region of Tataouine (Tunisia)]. Etudes et Thèses. Paris. ORSTOM pp. 317.

Escadafal R., Mulders M., Thiombiano L. 1995. Surveillance des sols dans l'environnement par Télédétection et Systèmes d'Information Géographique [Monitoring of soils in the environment by remote sensing and Geographic Information systems]. Actes du symposium international AISS, Ouagadougou (Burkina Faso) du 6 au 10 février 1995 pp. 619.

GIRARD M. 1975. Apport de la télédétection à la cartographie des sols: Possibilités, limites [Contribution of remote sensing for mapping of soils: possibilities, limitations]. 1er colloque «pédologie-télédétection». Rome, 1977 p. 221-231.

GIRARD M. 1977. Télédétection de la surface du sol [Remote sensing of the surface of the ground]. 1er colloque «pédologie-télédétection». Rome 1977 p. 5564.

GIRARD M. 1983. Télédétection de la surface du sol [Remote sensing of the surface of the ground]. Les colloques de l'INRA. Application de la télédétection à l'agriculture. Séminaire Paris 5, 6 et 7 Dec. 1983 p. 177-193.

GIRARD M., GIRARD C. 1989. Télédétection appliquée. Zones tempérées intertropicales [Applied remote sensing in intertropical temperate zones]. Partie pédologie p. 192-233.

Khali Issa L., Ben Hamman Lech-Hab K., Raissouni A., El ARrim A. 2016. Cartographie quantitative du risque d'érosion des sols par Approche SIG/USLE au niveau $\mathrm{du}$ Bassin versant Kalaya (Maroc Nord occidental) [Quantitative mapping of soil erosion risk using GIS/USLE approach at the Kalaya Watershed (North Western Morocco)]. Journal of Materials and Environmental Science. Vol. 7. No. 8 p. 2778-2795.

KING D. 1994. Apport de la télédétection à l'étude de la couverture pédologique. Revue des travaux menés au service d'étude des sols et de la carte pédologique de France [Contribution of remote sensing in the study of the soil cover. Review of the work to the study of soils and the soil map of France service]. Bulletin de la Société Française de Photogrammétrie et de Télédétection. No. 134 p. 15-20.

Mostephaoui M., Merdas S., Sakaa B., Hanafi M., BenAzzouz M. 2013. Cartographie des risques d'érosion hydrique par l'application de l'équation universelle de pertes en sol à l'aide d'un système d'information géographique dans le bassin versant d'El hamel (Boussaâda) Algérie [Mapping of water erosion by the application of the universal equation of loss of ground using a geographic information system in the catchment area of El Hamel (Boussaada) Algeria]. Journal algérien des régions arides. $\mathrm{N}^{\circ}$ spécial. p. 131147.

NAERT B. 1977. Méthodologie de l'application de la télédétection à la cartographie des sols. Premières conclusions obtenues à partir de traitements photogra- 
phiques des données [Methodology for the application of remote sensing for mapping of soils. First conclusions obtained from photographic processing of data]. 1er colloque «pédologie-télédétection». Rome p. 297310 .

Renard K., Foster G., Weesies G., Mccool D., Yoder D. 1997. Predicting soil erosion by water: A guide to conservation planning with the Revised Universal Soil Loss Equation (RUSLE). U.S. Department of Agriculture. Agriculture Handbook. No. 703. ISBN 0-16-048938-5 pp. 384.

SAdiki A., Bouhlassa S., SAÏdAti J., AuajJar J., Faleh A., MACAIRE J. 2004. Utilisation d'un SIG pour l'évaluation et la cartographie des risques d'érosion par l'Equation universelle des pertes en sol dans le Rif oriental (Maroc): Cas du bassin versant de l'oued Boussouab [Use of a GIS for assessment and mapping of erosion risks by the Universal Equation of Soil Loss in the Eastern Rif (Morocco): Case of the Ououss Boussouab watershed]. Bulletin de l'Institut Scientifique, Rabat, section Sciences de la Terre, ${ }^{\circ} 26$. p. 69-79.

SChWAB G., Frevert R., DMinster T., Barnes K. 1966. Soil and water conservation engineering. 2 ed. New
York. John Wiley. The Fergunson Foundation Agricultural Engineering Series pp. 683.

SMith D.D., WischmeIER W.H. 1957. Factors affecting sheet and rill erosion. Transactions of the American Geophysical Union. Vol. 38 p. 889-896.

Smith D.D., WischmeIER W.H. 1962. Rainfall erosion. Advance in Agronomy. Vol. 14 p. 109-148.

Soutter M., Mermoud A., Musy A. 2007. Ingénierie des eaux et du sol processus et aménagements [Water and Soil Engineering Processes and Facilities]. PPUR. Lausanne, Suisse. ISBN 2880747244 pp. 294.

Wall G., Baldwin C., Shelton I. 1987. Soil erosioncauses and effects. OMAFRA Factsheet 87-040 [online]. [Access 04.01.2017]. Available at: http://www. omafra.gov.on.ca/english/engineer/facts/12-053.htm

WischmeIER W., MANNERING J. 1969. Relation of soil properties to its erodibility. Soil Science Society of America Proceedings. Vol. 33. Iss. 1 p. 131-137.

WischmeIER H., SMITH D. 1978. Predicting rainfall erosion losses. A guide to conservation planning. Agriculture Handbook. No. 537. Washington, DC. USA. USDA pp. 58.

\section{Maamar MEGHRAOUI, Mohamed HABI, Boutkhil MORSLI, Mohamed REGAGBA, Abdelhakim SELADJI}

\section{Mapowanie erozyjności gleb i ocena strat gleby w górach Sebaa Chioukh (północno-zachodnia Algieria) za pomocą modelu RUSLE}

\section{STRESZCZENIE}

Erozja i transport zawiesiny stanowią w Algierii główne ograniczenie rozwoju rolnictwa i zarządzania infrastrukturą hydrotechniczną (ponad 20\% urządzeń jest zamulonych). Z powodu nieregularnych opadów typowych dla półpustynnych obszarów śródziemnomorskich, topografii rejonów górskich, wrażliwości gleb, braku pokrywy roślinnej i niewłaściwych systemów upraw w górach Sebaa Chioukh o zróżnicowanej topografii występują częste i gwałtowne powodzie. Dlatego bezwzględnie konieczne jest dokonanie oceny (w skali przestrzennej i ilościowej) skutków erozji glebowej w celu zmierzenia się z tym zjawiskiem i zaproponowania najlepszej strategii ochrony i gospodarki przestrzennej. Przedstawione badania miały na celu wykonanie map erozyjności gleb z użyciem teledetekcji i systemu GIS z uwzględnieniem typów gleb. Aby to osiagnąć, obliczono współczynniki w równaniu RUSLE. Uzyskane wyniki dowodzą, że 26760 ha, tzn. 56,58\% obszaru badań, doświadcza rocznych strat gleby w ilości od 150 do $200 \mathrm{t} \cdot \mathrm{ha}^{-1}$. Obszar badań położony jest na glebach krzemionkowo-żelazistych i vertisolach występujących szczególnie na terenach niewykorzystywanych rolniczo o dużym stopniu nachylenia.

Słowa kluczowe: GIS, góry Sebaa Chioukh, model RUSLE, teledetekcja 